Буба Стојановић

Универзитет у Нишу

Педагошки факултет у Врању
$371.3:: 821$

821-342

https://doi.org/10.18485/filkult.2016.2.ch7

\title{
ЈЕЗИК БАСНЕ И КУЛТУРА МЛАДИХ
}

\section{Сажетак}

Басна као књижевна врста својим језиком и стилом, хумором и оптимизмом значајно утиче на васпитање младих и њихово понашање. Богата кратким, језгровитим дијалозима између две супротности које наизгледделују непомирљиво басна богати речник ученика учтивим фразама, доприноси културном понашању, пристојном обраћању и лепом поступању. Учи да „лепа реч и гвоздена врата отвара“, а „прејака може да убије“, да „језик више глава посече него сабља“.

Тумачењем басне, почев од предшколског и основношколског узраста, језичко-стилском анализом можемо успешно васпитавати ненасилну комуникацију код младих и значајно допринети хуманом понашању у широј друштвеној средини.

На примеру басни „Лав и миш“, „Лисица и рода“, „Лисица и гавран“ и „Вук и јагње“ показаћемо вредност дијалога, могућности богаћења речника, као и развијање социјалне интелигенције младих.

Кључне речи: басна, дијалог, култура, млади, васпитање.

\footnotetext{
Само се четири ствари не могу вратити: изгворена реч, избачена стрела, протекли живот и пропуштена прилика. арапска пословица
} 


\section{Увод}

Промене кроз које пролази савремено друштво директно разарају породицу и тиме стварају погодно тло за појаву насиља, како одраслих над децом, тако и међу децом што за последицу има неадекватно социјално окружење. Млади из непотпуних или социјално и егзистенцијално угрожених породица рефлектују начин комуникације у породици кроз понашање према другима, посебно према вршњацима. Горући проблем савременог друштва, па и савремене школе је стално присутно насиље без обзира на средину у којој се налази. Насилничко понашање, упозоравају многи, присутно је почев од предшколске установе, преко основне, а најизраженије је у средњој школи. У почетку вербална «борба» временом прераста у физички обрачун младих који може да има озбиљне последице по даљи развој личности, а често и смртни исход.

Говор као једна од важних, ако имамо у виду његову тесну везу са мишљењем, можемо рећи и најбитнијих одлика човека, требало би да буде оно што прати или претходи свим активностима у односу са другима. Посебно је важан говор као модел младима за васпитање у духу хумане личности. Поставља се питање шта бива са говором у време виртуелне стварности коју сви мање - више живимо? Електронска комуникација, стални пратилац савременог друштва, не развија говор, а тиме ни заједништво, солидарност, не гради хумано окружење, већ ствара велику дистанцу међу људима, неку врсту изолације на коју свакодневно пристајемо. Има аутора који сматрају да „масовна култура, идеологија и вредности потрошачког друштва доприносе формирању делимичне псеудоличности, конформистичке аморалне особе лишене духовног богатства, хуманистичких вредности и индивидуалног карактера (Лихачев 1995), што продукује недовољно квалитетну комуникацију са другима. У таквом окружењу провладава говор мржње, насиље и ниподаштавање другог.

Комуникационе компетенције у тесној су вези са социјалним компетенцијама. Истовремено су услов и показатељ квалитета социјалног живота појединца. Одражавају његову способност да комуницира са другима, успоставља квалитетне односе, доприноси прогресивном понашању и сарадњи у смислу суживота са околином. Ове 
компетенције подразумевају развијена интересовања младих за говор, читање и писање, богаћење речника, могућности да се та интересовања задовоље. Савремени медији снажно емоционално утичу на младе, а путем емоција (посебно негативних које изазивају) опасно делују на све аспекте личности. Зато је потребно више тежити успостављању непосредне комуникације међу младима како би успешно развили комуникационе, а тиме и социјалне компетенције, пријатне емоције и говор мржње и нетрпељивости заменили алтруизмом и емпатијом.

Посебну вредност у свему томе имају пажљиво бирани садржаји књижевности чијом се успешном обрадом може богатити речник, али и духовни свет најмлађих, формирати систем правих вредности, пожељно понашање, морално поступање. Басна је ту незаменљива.

\section{Књижевна уметност, комуникационе компетенције и култура младих}

Комуникација као динамичан систем размене речи, емоција, мисли и других видова вербалних и невербалних порука, можда је јединствени планетарни феномен који је будан 24 часа и сваки наредни (Кеверески, Љ., Старц, Ј. 2011: 14). Етимолошки корен речи комуникација, у латинском communis, у основи значи учинити општим, заједничким, што је корен од два појма који су тесно повезани са комуникацијом: „заједништво“ и „заједница“. Основна карактеристика комуникације схваћене на овај начин јесте интеракција између две или више особа једне заједнице при чему свака од њих то општење доживљава као пријатност, задовољство, испуњеност; самопотврђивање изражавањем личног става о одређеном проблему или појави. У свакодневном животу комуникација представља кључну карику у споразумевању међу људима, механизам помоћу кога појединац изражава потребе, ставове, мишљење, чиме успоставља социјалне односе са околином. Узависности од квалитета комуникације зависиће и степен задовољства појединца односима са окружењем.

Савремена сазнања потврђују да се вештине комуникационих и социјалних компетенција манифестују већ од пете године живота када је дете у стању да респектује туђа осећања. Самим тим највећу 
одговорност за квалитет социјално - комуникационих предиспозиција сноси породица и породично окружење у коме дете успоставља прве односе са другима, изговара прве речи, слуша саговорника, прихвата позив за говорну и социјалну активност, учи се понашању.

Игра има велики значај за укупан развој деце, посебно ако је праћена говором и симулацијом одређених животних ситуација. Корисна је и функционална у остваривању бројних васпитних и образовних циљева наставе, а тиме и у развоју језичких и социјалних компетенција. Бројне језичке и говорне игре које се користе у раду са децом предшколског узраста, али и касније, значајно подстичу развој говора и успостављање исправног односа према другом (видети више у Стојановић 2015: 57-76). Почев од успаванки, ташунаљки, цупаљки, лазаљки, бројалица, брзалица све језичке игре обезбеђују интелектуалну активност, радозналост, осетљивост, подстичу развој емоција и маште, сарадњу са вршњацима, усвајање друштвених облика понашања, стицање јасне представе о себи, социјализацију и друштвено-морални развој (Наумовић 2001: 58).

Непосредни контакт одраслог и детета, игра речима, разговор о делу, анализа ликова, дискусија о поступцима и понашању и други облици вербалне комуникације добар су начин да подстакнемо говор, али и негујемо критичко мишљење, оштроумност, проницљивост, сналажљивост, развијамо толерантност, хуманост, алтруизам.

Књижевност као уметност речи открива нам сложену животну филозофију, расветљава међуљудске односе, омогућава да спознамо вишевековне животне мудрости. Нуди широку лепезу позитивних ликова -јунака који нас уче хуманости, човекољубљу, откривају начине како да приђемо другоме, проникнемо у његову душу, отворимо срце, испунимо га пажњом, нежношћу и топлином.

Реч као посебан феномен веома је моћно оружје како у позитивном тако и у негативном смислу. Опште је познато да „језик може више глава да посече него сабља“. О томе посебно треба водити рачуна данас у време израженог вербалног насиља које временом прераста у физичко. С обзиром на то посебно су драгоцене учтиве фразе које треба уводити у говор детета одмалена. На пример, стихови који следе добар су повод за разговор са децом предшколског узраста о лепом понашању, поступању према другима, пажљивом односу, толеранцији, међусобном уважавању: 


\section{Филологија културе}

Постоје четири чаробне речи, којима се ружно понашање лечи, за њих зна свако ко другарство воли:

ХВАЛА,

МОЛИМ,

извини,

ИзВОЛИ.

Помоћу тих кратких чаробних речи

свака се свађа и свака туга лечи...

И код куће и у школи:

ХВАЛА,

МОЛИМ,

ИзВИни,

изволи.

Култура живљења у савременом свету, између осталог подразумева, међусобно поштовање, уважавање, толеранцију. Креч, Кречфилд и Балаки под појмом култура подразумевају образац свих поступака материјалне природе и понашања, које је друштво усвојило као традиционалне начине за решавање проблема својих чланова. Култура обухвата институционализоване начине и имплицитна културна веровања, вредности и премисе, које сачињавају основу понашања и њим управљају (Kreč i sar. 1972: 386). Културно понашање представља одговор на главне проблеме друштва, начин решавања свих конфликтних ситуација, облик ступања у квалитетне односе са другима у окружењу.

Књижевна дела за децу, посебно басне духовно оплемењују, подстичу хуманост, негују толеранцију, богате речник, доприносе оштроумности и сналажљивости у проблемским ситуацијама. Млађи нараштаји уз адекватно методичко усмеравање васпитача, учитеља, наставника сигурни су градитељи хуманијег света. Обрадом лектире, уз активно учешће реципијента током анализе проблемских ситуација, поступака и понашања ликова, разоткривањем њихових 
особина, тражењем узрока и последица, осудом зла и величањем добра, подстичу се пожељни облици друштвеног понашања. У раду са децом вешт васпитач, учитељ или наставник на примеру књижевног јунака може да открије начине конструктивног решавања проблема и предности позитивне комуникације. Негативни ликови, такође, могу послужити како би ученици стекли увид у последице које непожељно и агресивно понашање и насилна комуникација могу да имају по онога ко се тако понаша. Стара кинеска пословица каже: кажи ми и заборавићу, покажи ми - можда ћу се сетити, укључи ме и научићу. Имајући у виду вредности басне као књижевне врсте: динамику, ликове анималног света, дијалог, хумор, могућности за домаштавање и сценско извођење, а тиме и активно укључивање читаоца у обраду, сматрамо је посебно погодном за васпитање толерантног понашања и ненасилног поступања.

\section{Ликови у басни као узор ненасилној комуникацији}

Басна је својом краткоћом, згуснутим језиком, симболиком и метафорама, с једне, и многозначношћу, дубоком животном филозофијом, с друге стране, била, јесте и биће предмет тумачења многих научних дисциплина. Од свог постанка па све до данас басна заузима значајно место у програму предшколског и млађег основношколског узраста. Интернационални мотиви и универзалне поуке носе печат културе у оквиру које је настала. Ако је једноепизодична, заснована је на једној идеји. Уколико је двоепизодична почива на контрасту. Јављање поучности може се "протумачити усвајањем поновљеног, практичног, појединачног и колективног искуства, које се временом систематизовало у одређене схеме" (Маљковић 2007: 30).

Као таква, басна је погодна како за реализацију образовних, тако посебно васпитних и функционалних задатака наставе. Књижевни лик у њој има велику вредност. Има "своје значење, структуру, функцију и смисао. Као и само књижевно дело и лик је вишеслојна творевина, састављена од више различитих елемената, снагом стваралачког духа обједињених у јединствену целину" (Милатовић 2011: 318). Ликови у баснисуживотиње.Срећемо ихунеочекиванимизањихнеуобичајеним 
ситуацијама. Хумор који избија из сваке од тих ситуација чини је само наизглед комичном. Уколико дубље заронимо у психологију ликова, како позитивних, тако и негативних, налазимо богат материјал за моралну анализу и формирање етичког става младих.

Посебно је драгоцен дијалог у басни којим се откривају карактерне црте ликова. Иако језгровит говор ликова је симболичан и метафоричан. Алегоријски смисао чини је нарочито захвалном у развијању комуникационих и социјалних компетенција. Тумачењем уметничког света преносе се и откривају "етнопсихолошка својства житеља, особености поднебља, понашања и односи у одређеној средини" (Милошевић-Ђорђевић, Н. 1996: 14), из које је потекла што је погодно за упознавање и прихватање различитости. Драматика уз обавезну супротност јавља се између две равни које истовремено "расту", распламсавају се, кулминирају. Све то чини басну погодном за разматрање многих конфликтних ситуација и откривање функционалних решења применљивих у свакодневном животу.

Служећи се различитим средствима карактеризације писац даровити приповедач у народу ликове басне обликује доводећи их у ситуације у којима се поступцима и говором испољавају карактерне особине људи. Сликања лика путем језика је посебан начин стварања. Анализом језика басне ликови се разоткривају како по физичким особинама, тако и по карактеру који се испољава пажљиво бираним речима. Тако упознајемо "снагу" лава и сналажљивост миша у истоименој басни Лав и миш, жељу снажног бика и став плашљивог зеца у басни Бик и зец, лукавост лисице у бројним баснама у којима је она главни актер (Лисица и гавран, Лисица и лав, Старо лијино лукавство...), прождрљивост вука, али и досетљивост досад наивних јагањаца (Вук и јагње), разумност коза (Две козе), тврдоглавост јараца (Два јарца), скромност и упорност корњаче, уображеност зеца (Корњача и зец), безобзирност коња и немоћ магарета (Коњ и магаре), слаткоречивост лисице и домишљатост роде (Лисица и рода) и друге важне особине, врлине и мане, које треба уочити.

Успостављајући паралелизам животиња - човек ученици препознају у особинама и поступцима животиња карактере људи. Анализом језика истила могућеје развијати обликеучтивогпонашања, као и моделе културног поступања.Тако рецимо, при обради басне Лисица и рода деци треба скренути пажњу на љубазност лисице коју 
испољава на почетку, као и гесту који чини приредивши ручак како би "углостила" роду. Рода се, такође, љубазно захваљује не схватајући намеру лукаве лисице.

...Хвала, хвала! - одговори рода задовољно (када је угледала и осетила мирис укусне чорбе), али изненада схвати какву јој је неслану шалу приредила лисица (јер својим кљуном није могла да једе из плитког тањира). Видевиши да не једе лисица се као љути: Зар ти се не свиђа ручак? Специјално сам га за тебе припремила! - рече злобно се насмејавши.

Осим чуђења и наизглед забринутости што рода не једе злобан осмех и коментар да је специјално за њу припремљен ручак пружа аргументе роди да буде груба, да се оштро супротстави лисици бурно и реагује, али она то не чини. Таквом реакциојом више би рекла о себи, а то није желела, зато се одлучује за наставак игре. Увређена, али и домишљата, одговорила је:

Извини, молим те, али одједном ме ухватила страшна главобоља и потпуно сам изгубила апетит!

На то лисица даље наставља речима:

Штета, а тако добра чорба. Али, добро биће још прилике!

Ту прилику је рода и чекала. Сада јој узвраћа предлогом:

Одлично! Могла би ти да навратиш код мене на ручак сутра? Тако ћу моћи да ти узвратим твој љубазни позив.

Скоро увек лукаву лисицу су овог пута надмудрили. Сутрадан долази на ручак код роде, где нажалост само може да гледа богато припремљену рибљу чорбу, јер је рода послужила у високим посудама са уским грлом. Гледајући роду која сласно једе лисица је размишљала о свему што се десило протеклих дана. Враћајући се кући ...зачула је у себи тихи гласић који јој је рекао: Како си сејала, тако ћеш и жети. (www.waece.org/paz/bosnia/23.\%20Pravednost.pdf посећено 29.10.2016.)

Језик као основно средство књижевног изражавања треба посматрати у контексту. У овом случају осим што се богати речник ученика оплемењује се његова личност, учи културном понашању, љубазности, стрпљењу, толерантности. Пожељно је радити на формирању критичког става према манама које треба кориговати. Важно је анализирати и позитивне стране у понашању негативних 
ликова, у овом случају лисице (њену љубазност, гостољубивост, брижљивост, слаткоречивост коју показује), одбацујући технику црнобелог сликања. Рефлексијом на стварност откривањем и позитивних елемената у понашању негативног јунака ученици ихмогу искористити у одређеним стуацијама, наравно без такве позадине.

Занимљиво је задржати се на још неким примерима басни чијом се језичком анализом ученици могу упутити у тајне успешног комуницирања. Тако рецимо, у већ у I разреду упознају Доситејеве басне Два јарца и Две козе. Анализом тврдоглавости јараца и разумности коза могуће је подстицати их да осмисле дијалог јараца с обзиром на познати исход. Даље је могуће давати предлоге како су могли договором мирно да реше проблем. Сусрет коза на узаној стази је, такође, добра прилика да се осмисли њихов разговор и вербално пропрати решавање проблема.

Подстакнут овим баснама Душко Трифуновић пише стихове о два јарца који су мудро поступили упркос другачијим очекивањима. Окупљени навијачи очекују добро познати исход истоимене басне, навијају и чекају да виде ко је јачи. Међутим, јарци се само у почетку мере по снази, почињу са увредама:

...склањај ми се ружна стоко

бацићу те у дубоко...

а онда,

...кад су дошли насред моста

један рече - сад је доста

и са једне стране и са друге стране

... вратимо се свако себи

да до туче дошло не би

ни са једне ни са друге стране

...вpamume се па се смију

пусти људе да се бију

и са једне и са друге стране.

(Деца могу да полете стр.19). 
У II разреду у програму је народна басна Лисица и гавран (Манојловић, Бабуновић 2007: 57) у којој лукава лисица опази да гавран има повећи комад сира који чврсто држи у кљуну. Зато мудро, без примене силе, слаткоречивошћу успева да похвалама придобије лакомисленог гаврана како би испустио комад сира. Знајући његове мане, али и жељу да упркос томе буде савршен, ласкањем постиже свој циљ, па каже:

Ти си веома лепа птица - имаш прекрасно перје! Нико на свету не би био тако савршен као ти, само кад би умео да певаши!

Циљајући му у Ахолову пету лисица успева у својој намери. Гаврану се није свидело да поред толике своје лепоте има и неки недостатак, те он отвори кљун и загракта. Тада му испаде комад сира који лисица брзо зграби и побеже говорећи: E, мој гавране имаш и гласа и сјаја, али немаш памети" (Манојловић, Бабуновић 2007: 57).

На примеру лисице млади могу уочити да "лепа реч и гвоздена врата отвара". У овом случају ласкавост лисице јепонела лакомисленог гаврана жељног славе да изгуби свој плен. Његова сујета је толико велика да је лукавој лисици мало требало да успе у својој намери.

Умиљатост и речитост препознајемо и код маленог миша који тако покушава да се искупи за своју несмотреност у басни Лав и миш. Притом обећава и нешто у шта цар животиња на први поглед не може ни да поверује. Обраћајући се речима: Молим те, поштеди ме, а ја ћу ти се кад - тад одужити, миш открива да је свестан лавове снаге, моћи и прождрљивости, али ипак рачуна на његову величину, не само у физичком, већ и у духовном смислу. Смејући се на његове речи лав га ипак невољно пушта с неверицом да ће му икада затребати помоћ тог маленог створа. Међутим, "коло среће се окреће" те се врло брзо лав нађе у мрежи ловаца. Његову беспомоћну рику чуо је једино миш који је одржао реч, ослободио га и искористио прилику да му укаже на велику грешку: да друге "не мери пеђу, већ памећу".

У народној басни Вук ијагње, такође, анализом разговора између препреденог вука и само наизглед наивних јагњади, откривамо да су речи моћно оружје у позитивном или негативном смислу. Дијалогом 
између искусног вука и домишљатих јагањаца даровити народни приповедач је доказао да ум царује снага кладе ваља. Најпре је вук, стари препредењак, бираним речима, иза којих крије истинску намеру, настојао да се приближи јагањцима рачунајући на њихову наивност и неискуство, те каже:

О јагњићи, моји младунчићи! Тако нам лијепе наше љубави, нека дође један од вас да ми извади једну кост што ми је запала у грло!

(Цветковић М. и сар., 2009: 37).

Анализом његових речи запажа се скривена намена (када се куне у љубав њихову). Међутим, вук не рачуна на усмену школу којом се проверене истине преносе с колена на колено. Традиционално васпитање младих на темељима предања опажа се у одговору јагањаца који, иако можда немају довољно искуства, задојени духом предака и старине знају да "вук длаку мења, али ћуд никада". Упркос "љубави" у коју се куне не верују том ласкавцу. Свесни своје недовољне снаге позивају се, врло бираним речима, оштроумношћу и домишљатошћу, на своје спасиоце - чобане.

Мудрост њихова је велика. Надајући се да ће уплашити вука и сами покушавају да се ишчупају из неприлике позивајући се на чобане:

Ми бисми драге воље да је авлија отворена, него идемо позвати чобане да отворе, и они ће ти најбоље и највештије кост извадити.

(Цветковић М. и сар., 2009: 37).

Анализом одговора открива се њихова сналажљивост, мудрост, домишљатост, али и љубазност иза које се скрива храброст да му истом мером врате и тако га победе у надмудривању.

\section{Закључак}

Слојевитошћу и вишезначношћу, хумором и дијалогом, анималним јунацима и алегоријом уметнички свет басне снажно 
се рефлектује на личност реципијента кроз бројне компетенције које се тичу комуникације, социјализације, самопотврђивања, али и креирања позитивног и прогресивног окружења, усвајањем облика културног понашања. Читањем басни доказује се Радовићева теза да „уђеш у књигу мали, изађеш велики“; велики не само по речима, већ и по делима.

На основу наведених примера, али и шире, може се закључити да су басне веома погодно штиво за развој пожељне комуникације, толеранције и културног понашања. Читајући их и промишљајући о догађајима, ликовима, њиховим поступцима и понашању млади упознају комплексност живота, откривају различитост људске природе, уче моралне вредности. У центру басне је бескрајна човекова жеља за животом, али и слогом, пријатељством, осуда насиља, неправде, зла. Логика здравог разума и толерантно понашање у свакој конфликтној ситуацији карактеристичној за басну нуде читаоцу могућност да открије тајне успешног комуницирања, конструктивног решавања проблема, успостављања квалитетних односа, стварања подстицајног окружења.

Ликови у басни добар су повод за дискусију о различитим типовима људи, свакодневним ситуацијама, животним проблемима, начину њиховог решавања, могућностима исправног поступања.

Дијалог је посебна вредност басне. Њиме се откривају различити карактери личности, богати речник и духовно обликује младо биће. Тумачењем језика басне може се дискутовати о томе шта се крије иза речи одређеног лика, какав карактер је у питању, које особине су "насликане", које се мане осуђују, зашто, али и како се треба понашати у сличним ситуацијама, како реаговати, шта предузети, да ли вратити и на који начин "мило за драго".

Текст басне подстиче младе да размишљајући о поступцима јунака размишљају и о својим поступцима, преиспитују себе, своје речи и дела, коригују понашање и унапређују односе са околином у циљу стварања квалитетне продуктивне и прогресивне средине неопходне за несметани развој и опстанак свих чланова једне заједнице. 


\section{Филологија културе}

\section{Литература:}

Лихачев, Б., Т. Филозофия васпитания. Москва. 1995.

Кеверески, Љупчо Комуникација у школи данас путоказ за сутра. Педагошка стварност LVII, 5-6. Нови Сад. 2011.

Кеверески, Љупчо, Старц, Јасмина. Психологија на комуникација. Битола: Киро Дандаро. 2011.

Kreč, D, Krečfild, R. i Balaki, I. Pojedinac u društvu. Beograd: Zavod za udžbenike i nastavna sredstva Srbije. 1972.

Маљковић, Миланка. Басна лектира мудрости. Нови Сад: Змај, ДОО. 2007.

Милатовић, Вук. Методика наставе српског језика и књижевности у разредној настави. Београд: Учитељски факултет у Београду. 2011.

Милошевић-Ђорђевић, Нада. Од бајке до изреке. Београд. 1996.

Наумовић, Милорад. Методика развоја говора. Пирот: Виша школа за образовање васпитача. 2001.

Стојановић, Буба. Вредности народне књижевности у настави. Врање: Учитељски факултет Врање. 2015.

Стојановић, Буба. Ликови у књижевним делима и ненасилно понашање ученика. Школа у природи као фактор социјализације и могућности сузбијања насиља у школи, Врање: Учитељски факултет. стр.353-362. 2011.

\section{Извори:}

Манојловић, М., Бабуновић, С. Читанка за други разред основне школе. Боград: Едука. 2007.

Цветковић М. и сар. Водено огледало, читанка за 3. разред основне школе. Београд: Едука. 2009.

Деца могу да полете, читанка за предшколце, Београд: Креативни центар.

Жежељ- Ралић, Р. Игра речи, читанка за први разред основне школе. Београд: Клет. 2007.

Лисица и рода по Езопу, текст басне, www.waece.org/paz/bosnia/23.\%20Pravednost. pdf посећено 20.10.2016. 


\author{
Buba Stojanović \\ University in Niš \\ Pedagogical faculty in Vranje
}

\title{
LANGUAGE OF FABLES AND THE YOUTH CULTURE
}

\section{Summary}

Fable as a literary genre with its language and style, humour and optimism significantly influences education of the youth and their behavior. Rich with short, essential dialogues between the two opposites which are seemingly irreconcilable, fable enriches students' vocabulary with polite phrases, contributes to cultural behavior, polite remarks and good manners. It teaches us that ' nice words open iron doors', and that 'a word too strong can kill', that 'language cut more heads off than a saber'.

By interpreting fables, starting from preschool and primary school age, with linguistic and stylistic analysis we can successfully educate nonviolent communication between young people and greately contribute to humane behavior in a broader social environment.

Using the examples of fables 'The lion and the mouse,' 'The fox and the stork', 'The fox and the raven' and 'The wolf and the lamb' we will show the value of dialogue, the possibility of enriching students' vocabulary as well as developing social intelligence of the young people to accept differences and overcome the opposites.

Key words: fable, dialogue, culture, youth, upbringing. 